\title{
ANALISIS FAKTOR-FAKTOR YANG MEMPENGARUHI KONSUMSI BUAH- BUAHAN PADA SKALA RUMAH TANGGA DI KOTA MATARAM
}

\section{ANALYSIS OF FACTORS AFFECTING THE CONSUMPTION OF FRUITS ON HOUSEHOLD SCALE IN MATARAM CITY}

\author{
Azka Iklilah Alhudzaifah ${ }^{1}$, Anwar $^{2}$, dan Sri Maryati ${ }^{2}$ \\ ${ }^{1 *, 2,2}$ Program Studi Agribisnis, Universitas Mataram, Kota Mataram, Indonesia \\ *Email Penulis korespondensi: azkalillah@gmail.com
}

\begin{abstract}
ABSTRAK
Tujuan dari penelitian ini adalah: (1) Untuk menganalisis gambaran umum pola konsumsi buah-buahan pada konsumen rumah tangga di Kota Mataram; (2) Untuk menganalisis faktor-faktor yang mempengaruhi konsumsi buah-buahan pada konsumen rumah tangga di Kota Mataram. Unit analisis dalam penelitian ini adalah konsumen rumah tangga yang membeli dan mengkonsumsi buah-buahan di Kota Mataram. Analisis yang digunakan dalam penelitian ini adalah: Analisis Deskriptif dan Analisis Regresi Linier Berganda. Berdasarkan hasil penelitian dan pembahasan diperoleh kesimpulan sebagai berikut (1) buah yang paling banyak diminati oleh konsumen adalah buah lokal. Jenis buah yang dipilih untuk dikonsumsi oleh konsumen rumah tangga sangat bervariasi. Jumlah buah yang paling banyak diminati yaitu buah Jeruk Lokal, sedangkan yang paling sedikit diminati yaitu buah Alpukat Lokal dan Duku Lokal. (2) Faktor-faktor yang mempengaruhi konsumsi buah-buahan pada konsumen rumah tangga di Kota Mataram yaitu jumlah pendapatan, usia, jumlah anggota keluarga dan tingkat pendidikan berpengaruh nyata secara serempak terhadap jumlah konsumsi buah. Jumlah pendapatan, jumlah anggota keluarga, dan tingkat pendidikan berpengaruh nyata secara parsial terhadap jumlah konsumsi buah, sedangkan usia tidak berpengaruh nyata secara parsial terhadap jumlah konsumsi buah.
\end{abstract}

Kata Kunci: analisis faktor, buah-buahan, pola konsumsi, rumah tangga.

\begin{abstract}
The aims of this study were: (1) To analyze the general description of fruit consumption patterns in household consumers in Mataram City; (2) To analyze the factors that influence the consumption of fruits in household consumers in Mataram City. The unit of analysis in this study is household consumers who buy and consume fruits in Mataram City. The analysis used in this research are: Descriptive Analysis and Multiple Linear Regression Analysis. Based on the results of research and discussion, the following conclusions are obtained (1) the fruit that is most in demand by consumers is local fruit. The types of fruit chosen for consumption by household consumers vary widely. The number of fruits that are most in demand are local oranges, while the ones with the least demand are local avocados and local duku. (2) The factors that influence the consumption of fruit in household consumers in the city of Mataram, namely the amount of income, age, number of family members and education level have a significant simultaneous effect on the amount of fruit consumption. Total income, number of family members, and level of education partially significantly influence the amount of fruit consumption, while age does not partially significantly affect the amount of fruit consumption.
\end{abstract}

Keywords: consumption patterns, factor analysis, fruits, households.

\section{PENDAHULUAN}

Buah-buahan merupakan salah satu jenis tanaman hortikultura hasil produk sektor pertanian yang lebih bersifat tahunan, dan dikenal sebagai sumber vitamin dan mineral. Buah memiliki sumber yang baik dari antioksidan dan fitokimia seperti vitamin $\mathrm{C}$, karoten, flavonoid, dan poliphonel. Ada bermacam manfaat dari buah yang belum diketahui sehingga kadang membuat sebagian orang malas untuk mengkonsumsinya. Padahal mengkonsumsi buah setiap hari dapat membantu mencegah dan mengatasi berbagai penyakit serta dapat membuat tubuh sehat dan bugar (Dalimartha, 2011). 
Tingkat konsumsi buah di Indonesia selama beberapa kurun waktu terakhir menunjukkan kecenderungan terjadinya peningkatan (Wardani, 2007), sedangkan data konsumsi buah per kapita dalam sehari penduduk NTB masih jauh dari rekomendasi WHO (World Health Organization) dan Kementerian Kesehatan. WHO secara umum menganjurkan konsumsi buah untuk hidup sehat sejumlah 150 gram buah. Konsumsi buah sehari per kapita di NTB sebanyak 81,35 gram. Angka konsumsi buah dalam sehari untuk nasional sebesar 90,10 gram, konsumsi buah NTB masih lebih rendah dibandingkan konsumsi nasional dan anjuran dari WHO (Susenas, 2019).

Kota Mataram merupakan salah satu kota di Provinsi Nusa Tenggara Barat yang mempunyai kepadatan penduduk tertinggi. Salah satu komoditas yang dapat dikembangkan dalam rangka meningkatkan kesejahteraan masyarakat di Mataram umumnya dan masyarakat di pedesaan khususnya adalah komoditas hortikultura (Tanaya et al, 2021). Bertambahnya jumlah penduduk di Kota Mataram menyebabkan semakin berkembangnya masyarakat yang mulai membudidayakan berbagai jenis tanaman hortikultura.

Tanaman hortikultura merupakan komoditas yang baik untuk dikembangkan di daerah (Septiadi \& Nursan, 2021). Tanaman hortikultura memiliki dua kontribusi penting, yaitu sebagai sumber pemenuhan gizi penduduk (septiadi \& Mundiyah, 2020), dan menjadi salah satu sub sektor yang dapat menghasilkan nilai tambah. Salah satunya adalah jenis tanaman hortikultura yang bersifat menguntungkan yakni buah-buahan. Dalam pembangunan ekonomi, kontribusi buat-buahan tidak bisa dipandang sebelah mata. Banyaj jenis buah-buahan yang tumbuh subur di Indonesia (Wirawan \& Antara, 2013). Buah-buahan yang dihasilkan sangat bervariasi jenisnya dan kualitasnya. Meskipun Kota Mataram memiliki banyak variasi jenis buah dan ketersediaan buah yang cukup tinggi tiap tahunnya, ternyata tidak sesuai dan sebanding terhadap jumlah konsumsi buah pada masyarakat. Dibandingkan dengan jenis kelompok makanan lainnya konsumsi buah-buahan di Kota Mataram tergolong rendah. Konsumsi buahbuahan di Kota Mataram terbilang masih fluktuatif dan tidak stabil tiap tahunnya.

Idealnya, buah-buahan merupakan salah satu kelompok makanan yang wajib ada pada setiap porsi makanan sehari-hari. Konsumsi buah-buahan di Indonesia pada dasarnya sudah meningkat sebesar 8,21 persen dari sebelumnya $31,93 \mathrm{~kg} / \mathrm{kapita} / \mathrm{tah} u n$ pada tahun 2010 menjadi sebesar 34,55 kg/kapita/tahun pada tahun 2011 (Desfaryani et al, 2016). Namun angka tersebut masih jauh di bawah standar konsumsi yang direkomendasikan oleh FAO, yakni sebesar $73 \mathrm{~kg} / \mathrm{kapita} / \mathrm{tahun}$ (Hendriadi, 2013). Buah merupakan bagian yang penting dari pangan, karena mengandung banyak serat, air, vitamin dan mineral yang baik untuk gizi dan kesehatan. Buah juga termasuk dalam pola makan empat sehat lima sempurna. Analisis permintaan konsumsi pangan merupakan kajian yang masih menarik dalam khasanah penelitian pangan di Indonesia hingga saat ini (Sriwijayanti et al, 2004).

Berdasarkan uraian tersebut maka perlu dilakukan penelitian tentang "Analisis Faktor-faktor yang Mempengaruhi Konsumsi Buah-buahan pada Skala Rumah Tangga di Kota Mataram". Tujuan dari penelitian ini adalah untuk: (1) menganalisis gambaran umum pola konsumsi buah-buahan pada konsumen rumah tangga di Kota Mataram (2) menganalisis faktor-faktor yang mempengaruhi konsumsi buah-buahan pada konsumen rumah tangga di Kota Mataram. 


\section{METODE PENELITIAN}

Metode penelitian yang digunakan dalam penelitian ini adalah metode deskriptif. Jenis data yang digunakan dalam penelitian ini meliputi data kuantitatif dan kualitatif. Data yang digunakan dalam penelitian ini adalah data primer dan data sekunder. Unit analisis dalam penelitian ini adalah konsumen rumah tangga yang membeli dan mengkonsumsi buah-buahan di Kota Mataram. Penelitian ini dilaksanakan di tiga kecamatan yaitu, Kecamatan Ampenan, Mataram, dan Selaparang. Penentuan daerah sampel secara purposive sampling, atas dasar pertimbangan bahwa ketiga kecamatan tersebut memiliki jumlah rumah tangga yang lebih banyak dibandingkan kecamatan yang lainnya.

Penentuan jumlah responden ditetapkan secara quota sampling yaitu pengambilan sampel berdasarkan jumlah atau jatah yang telah ditentukan sebanyak 70 responden. Pengambilan sampel pada tiga kecamatan dilakukan secara proportional random sampling dengan penentuan responden secara acak berdasarkan jumlah rumah tangga masing-masing kecamatan.

Selanjutnya, penentuan konsumen rumah tangga yang menjadi responden dalam penelitian ini ditentukan secara accidental sampling yaitu konsumen rumah tangga yang kebetulan dijumpai pada saat survei dan bersedia untuk diwawancarai. Variabel dalam penelitian ini yaitu jumlah konsumsi buah, jumlah pendapatan, usia, jumlah anggota keluarga, dan lama pendidikan.

\section{Analisis Data}

\section{Pola Konsumsi Buah}

Untuk mengetahui pola konsumsi buah-buahan pada konsumen rumah tangga di Kota Mataram dianalisis secara deskriptif yaitu dengan mengamati dan menganalisis pola konsumsi buah rumah tangga di Kota Mataram. Pengamatan pola konsumsi buah ini dilaksanakan melalui wawancara dengan menggunakan kuisioner.

\section{Faktor-faktor yang Mempengaruhi Jumlah Konsumsi Buah}

Untuk mengetahui faktor-faktor yang mempengaruhi jumlah konsumsi buah pada konsumen rumah tangga di Kota Mataram, maka dilakukan analisis menggunakan Regresi Linier Berganda melalui program SPSS (Statistical Product and Service Solution) dimana sebuah variabel terikat (Y) dihubungkan dengan dua atau lebih variabel bebas (X). Untuk mengetahui variabel bebas (jumlah pendapatan, usia, jumlah anggota keluarga, dan lama pendidikan) terhadap variabel terikat yaitu jumlah konsumsi buah.

Formulasinya adalah sebagai berikut :

$$
Y=\alpha+\beta 1 X 1+\beta 2 X 2+\beta 3 X 3+\beta 4 X 4
$$

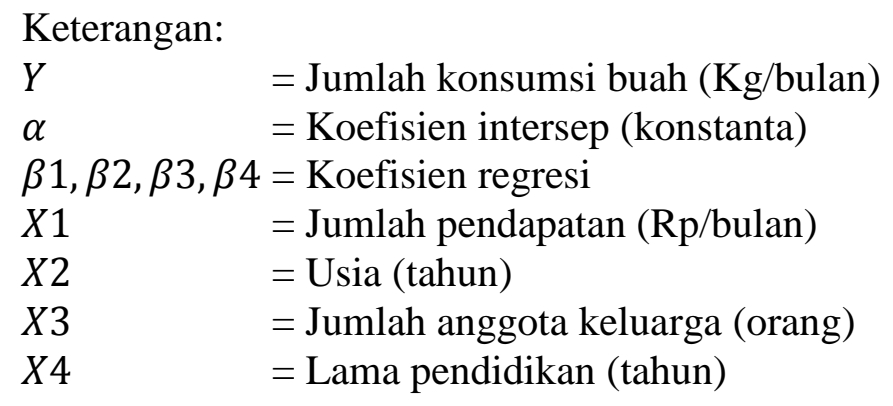




\section{Uji Kesesuaian Model (Test of Goodness of Fit)}

\section{Koefisien Determinasi $\left(R^{2}\right)$}

Koefisien ini merupakan suatu ukuran sejauh mana variabel bebas dapat merubah variabel terikat dalam suatu hubungan.

\section{Uji Serempak (Uji F - Statistik)}

Kriteria pengujian:

a. Jika sig. $\mathrm{F} \leq 0,05$ maka $\mathrm{H}_{0}$ ditolak dan $\mathrm{H}_{1}$ diterima.

b. Jika sig. $\mathrm{F} \geq 0,05$ maka $\mathrm{H}_{0}$ diterima dan $\mathrm{H}_{1}$ ditolak.

Dengan Hipotesis yang diajukan adalah:

Jika $\mathrm{H}_{0}$ ditolak dan $\mathrm{H}_{1}$ diterima artinya jumlah pendapatan, usia, jumlah anggota keluarga, dan lama pendidikan secara serempak berpengaruh nyata terhadap jumlah konsumsi buah.

Jika $\mathrm{H}_{0}$ diterima dan $\mathrm{H}_{1}$ ditolak artinya jumlah pendapatan, usia, jumlah anggota keluarga, dan lama pendidikan secara serempak tidak berpengaruh nyata terhadap jumlah konsumsi buah.

\section{Uji Parsial (Uji t - Statistik)}

Kriteria pengujian:

a. Jika nilai siginifkansi $\leq \alpha$ : maka $\mathrm{H}_{0}$ ditolak dan $\mathrm{H}_{1}$ diterima.

b. Jika nilai signifikansi $\geq \alpha$ : maka $\mathrm{H}_{0}$ diterima dan $\mathrm{H}_{1}$ ditolak.

Dengan hipotesis yang diajukan adalah:

Jika $\mathrm{H}_{0}$ ditolak dan $\mathrm{H}_{1}$ diterima artinya jumlah pendapatan, usia, jumlah anggota keluarga dan lama pendidikan secara parsial berpengaruh nyata terhadap jumlah konsumsi buah.

Jika $\mathrm{H}_{0}$ diterima dan $\mathrm{H}_{1}$ ditolak artinya jumlah pendapatan, usia, jumlah anggota keluarga dan lama pendidikan secara parsial tidak berpengaruh nyata terhadap jumlah konsumsi buah.

\section{Uji Asumsi Klasik}

Uji asumsi klasik adalah persyaratan statistik yang harus dipenuhi pada analisis regresi berganda yang berbasis Ordinary Least Square (Gujarati, 2006). Pada prinsipnya model regresi linier yang dibangun sebaiknya tidak boleh menyimpang dari asumsi BLUE (Best, Linier, Unbiased, dan Estimator). Ada tiga uji asumsi klasik yang akan digunakan dalam penelitian ini antara lain uji normalitas, heteroskedastisitas, dan multikolinearitas.

\section{HASIL DAN PEMBAHASAN}

\section{Karakteristik Responden}

\section{a. Jenis Kelamin Responden}

Berdasarkan hasil penelitian yang mewawancarai 70 orang konsumen rumah tangga dapat dikatakan bahwa sebagian besar lebih banyak perempuan berbelanja dan memutuskan pembelian buah-buahan. Hal ini dapat dilihat dari jumlah perempuan sebanyak 88,6\% dan laki-laki 11,4\%. Secara rinci dapat dilihat pada Tabel 1.

Tabel 1. Jenis Kelamin Responden Konsumen Buah di Kota Mataram Tahun 2021

\begin{tabular}{lcc}
\hline \multicolumn{1}{c}{ Jenis Kelamin } & Jumlah & Persentase (\%) \\
\hline Laki-laki & 8 & 11,4 \\
Perempuan & 62 & 88,6 \\
\hline Jumlah & 70 & 100 \\
\hline
\end{tabular}

Sumber: Data Primer Diolah (2021) 
Hal tersebut didukung oleh pendapat Priambodo (2014) yang menyatakan bahwa di Indonesia terdapat kecenderungan peran perempuan yang tinggi dalam proses pengambilan keputusan rumah tangga yang berkaitan dengan kebutuhan sehari-hari.

\section{b. Umur Responden}

Tabel 2. Umur Responden Konsumen Buah di Kota Mataram Tahun 2021

\begin{tabular}{|c|c|c|}
\hline $\begin{array}{c}\text { Kisaran Umur } \\
\text { (Tahun) }\end{array}$ & Jumlah & Persentase $(\%)$ \\
\hline $22-29$ & 13 & 18,6 \\
\hline $30-37$ & 9 & 12,9 \\
\hline $38-45$ & 15 & 21,4 \\
\hline $46-53$ & 26 & 37,1 \\
\hline $54-61$ & 7 & 10 \\
\hline Jumlah & 70 & 100 \\
\hline
\end{tabular}

Sumber: Data Primer Diolah (2021)

Jumlah responden terbanyak berada pada kisaran umur 46-53 tahun sebanyak 26 orang atau sebesar $37,1 \%$ dan jumlah responden terkecil berada pada kisaran umur 5461 tahun sebanyak 7 orang atau sebesar 10\%. Dapat disimpulkan bahwa responden konsumen buah berada pada kelompok umur produktif atau usia kerja, karena berada pada kisaran umur 15-64 tahun.

\section{c. Tingkat Pendidikan Responden}

Tabel 3. Tingkat Pendidikan Responden Konsumen Buah di Kota Mataram Tahun 2021

\begin{tabular}{lcc}
\hline \multicolumn{1}{c}{ Tingkat Pendidikan } & Jumlah & Persentase (\%) \\
\hline Tamat SD & 8 & 11,4 \\
Tamat SMP & 3 & 4,3 \\
Tamat SMA & 23 & 32,9 \\
Perguruan Tinggi & 36 & 51,4 \\
\hline Jumlah & 70 & 100 \\
\hline
\end{tabular}

Sumber: Data Primer Diolah (2021)

Berdasarkan Tabel 3 menunjukkan bahwa tingkat pendidikan responden konsumen buah terbanyak yaitu pada tingkat Perguruan Tinggi sebanyak 36 orang atau sebesar 51,4\% dan tingkat pendidikan terendah pada tingkat pendidikan SMP sebanyak 3 orang atau sebesar 4,3\%. Tingkat pendidikan responden berpengaruh terhadap keputusan membeli buah-buahan yang akan dikonsumsi. Tingkat pendidikan menentukan seseorang dalam menerima informasi dan pengetahuan (Sumarwan, 2015).

\section{d. Pendapatan Rumah Tangga Responden}

Tabel 4. Kisaran Jumlah Pendapatan per Bulan Responden Konsumen Buah di Kota Mataram Tahun 2021

\begin{tabular}{lcc}
\hline $\begin{array}{c}\text { Kisaran Pendapatan } \\
\text { (Rp/Bulan) }\end{array}$ & $\begin{array}{c}\text { Jumlah } \\
\text { (Orang) }\end{array}$ & $\begin{array}{c}\text { Persentase } \\
(\%)\end{array}$ \\
\hline $500.000-5.000 .000$ & 47 & 67,1 \\
$>5.000 .000-9.500 .000$ & 12 & 17,1 \\
$>9.500 .000-14.000 .000$ & 3 & 4,3 \\
$>14.000 .000-18.500 .000$ & 5 & 7,2 \\
$>18.500 .000$ & 3 & 4,3 \\
\hline
\end{tabular}




\begin{tabular}{ccccc}
\hline $\begin{array}{c}\text { Kisaran Pendapatan } \\
\text { (Rp/Bulan) }\end{array}$ & $\begin{array}{c}\text { Jumlah } \\
(\text { Orang) }\end{array}$ & & $\begin{array}{c}\text { Persentase } \\
(\%)\end{array}$ \\
\hline Jumlah & & 70 & & 100 \\
\hline Sumber: Data Primer Diolah (2021) & & & &
\end{tabular}

Berdasarkan Tabel 4 menunjukkan bahwa pendapatan rumah tangga konsumen yang mengkonsumsi buah di Kota Mataram terbanyak pada kisaran pendapatan $500.000-$ 5.000.000 perbulan sebanyak 47 orang atau sebesar $67,1 \%$. Besar kecilnya jumlah pendapatan rumah tangga secara langsung maupun tidak langsung berpengaruh pada pola konsumsi buah masing-masing keluarga. Pendapatan sangat mempengaruhi seseorang dalam memilih produk yang akan dikonsumsi (Simamora, 2004).

\section{e. Jumlah Anggota Keluarga Responden}

Tabel 5. Kisaran Jumlah Anggota Keluarga Responden Konsumen Buah di Kota Mataram Tahun 2021

\begin{tabular}{lcc}
\hline Jumlah Anggota Keluarga & Jumlah & Persentase (\%) \\
\hline $1-2$ & 21 & 30 \\
$3-4$ & 40 & 57,1 \\
$5-6$ & 9 & 12,9 \\
\hline Jumlah & 70 & 100 \\
\hline
\end{tabular}

Sumber: Data Primer Diolah (2021)

Berdasarkan Tabel 5 menunjukkan bahwa jumlah anggota keluarga konsumen yang mengkonsumsi buah di Kota Mataram terbanyak pada kisaran 3-4 orang sebanyak 40 orang atau sebesar $57,1 \%$. Jumlah anggota keluarga terkecil pada kisaran 5-6 orang sebanyak 9 orang atau sebesar 12,9\%. Hal tersebut sesuai dengan data dari Badan Pusat Statistik (BPS) Kota Mataram (2020), yang menyatakan bahwa rata rata jumlah anggota keluarga rumah tangga di Kota Mataram sebanyak 3-4 orang atau termasuk keluarga menengah.

\section{Pola Konsumsi Buah Konsumen Rumah Tangga di Kota Mataram}

\section{Minat Terhadap Buah}

Tabel 6. Minat Terhadap Buah pada Konsumen Rumah Tangga di Kota Mataram Tahun 2021

\begin{tabular}{llrrr}
\hline \multirow{2}{*}{ No } & Minat Terhadap Buah & $\begin{array}{c}\text { Jumlah } \\
\text { (Orang) }\end{array}$ & $\begin{array}{c}\text { Persentase } \\
(\%)\end{array}$ \\
\hline 1 & Buah Lokal & 50 & 71,4 \\
2 & Buah Impor & 20 & 28,6 \\
\hline & Jumlah & 70 & 100 \\
\hline
\end{tabular}

Sumber: Data Primer Diolah (2021)

Berdasarkan Tabel 6 menunjukkan bahwa minat terhadap buah pada konsumen rumah tangga di Kota Mataram terbanyak adalah pada buah lokal yaitu sebanyak 50 orang $(71,4 \%)$, sedangkan 20 orang $(28,6 \%)$ memilih buah impor. Hal ini menunjukkan buah lokal masih memiliki keunggulan yang positif yang bisa memenangkan faktor minat konsumen terhadap buah lokal dibandingkan buah impor. Hasil temuan ini sejalan dengan penelitian Yuliastuti et al, (2014) yang menunjukkan preferensi konsumen terhadap buah lokal (jeruk, papaya, pisang) lebih besar dibandingkan dengan buah impor (jeruk impor, apel impor, pir impor) terlihat dari nilai proporsi pengeluaran buah impor yang semuanya berada dibawah nilai proporsi pengeluaran buah lokal. 


\section{Jenis Buah}

Tabel 7. Jenis Buah yang Dipilih untuk Dikonsumsi oleh Konsumen Rumah Tangga di Kota Mataram Tahun 2021

\begin{tabular}{ccc}
\hline No & Jenis Buah & $\begin{array}{c}\text { Jumlah } \\
\text { (Orang) }\end{array}$ \\
\hline 1 & Alpukat Lokal & 2 \\
2 & Anggur Impor & 9 \\
3 & Apel Impor & 20 \\
4 & Duku Lokal & 2 \\
5 & Jeruk Impor & 8 \\
6 & Jeruk Lokal & 28 \\
7 & Kelengkeng Lokal & 3 \\
8 & Mangga Lokal & 4 \\
9 & Naga Lokal & 13 \\
10 & Pepaya Lokal & 21 \\
11 & Pir Impor & 7 \\
12 & Pisang Impor & 7 \\
13 & Pisang Lokal & 25 \\
14 & Salak Lokal & 5 \\
\hline
\end{tabular}

Sumber: Data Primer Diolah (2021)

Berdasarkan Tabel 7 diperoleh jenis buah yang paling banyak dipilih untuk dikonsumsi, pada setiap responden diketahui memilih lebih dari satu buah. Dengan demikian, dapat diketahui bahwa jumlah buah yang paling banyak diminati yaitu buah Jeruk Lokal, sedangkan yang paling sedikit diminati yaitu buah Alpukat Lokal dan Duku Lokal. Hal ini dikarenakan buah Jeruk Lokal lebih banyak tersedia dan mudah didapat oleh konsumen dibandingkan dengan buah Alpukat Lokal dan buah Duku Lokal yang jarang ditemukan karena lebih bersifat musiman dibandingkan jenis buah lainnya. Selain itu, alasan konsumen rumah tangga di Kota Mataram lebih banyak memilih buah jeruk untuk dikonsumsi karena faktor rasa dan kandungan yang dimiliki buah jeruk itu sendiri. Mengingat buah jeruk sangat mengandung vitamin $\mathrm{C}$ yang cukup tinggi.

\section{Kebiasaan Mengkonsumsi Buah}

Tabel 8. Kebiasaan Mengkonsumsi Buah pada Konsumen Rumah Tangga di Kota Mataram Tahun 2021

\begin{tabular}{llrr}
\hline No & Kebiasaan Mengkonsumsi Buah & $\begin{array}{r}\text { Jumlah } \\
(\text { Orang) }\end{array}$ & \multicolumn{2}{c}{$\begin{array}{c}\text { Persentase } \\
(\%)\end{array}$} \\
\hline 1 & Suka dan Sering & 42 & 60 \\
2 & Kadang-kadang & 28 & 40 \\
\hline & Jumlah & 70 & 100 \\
\hline
\end{tabular}

Sumber: Data Primer Diolah (2021)

Bersadasarkan Tabel 8 menunjukkan bahwa kebiasaan mengkonsumsi buah pada konsumen rumah tangga di Kota Mataram terbanyak adalah suka dan sering mengkonsumsi buah sebayak 42 orang (60\%), sedangkan sebanyak 21 orang (40\%) kadang-kadang mengkonsumsi buah. Dapat disimpulkan bahwa konsumen rumah tangga di Kota Mataram lebih banyak suka dan sering mengkonsumsi buah. Faktor kebiasaan pada dasarnya adalah penerimaan akan suatu hubungan pengaruh internal 
antara diri sendiri dengan sesuatu hal atau pengaruh eksternal dari lingkungannya, semakin kuat atau dekat hubungan tersebut semakin besar kebiasaan seseorang dapat terjadi. Faktor eksternal sendiri terjadi akibat pengaruh keluarga yang paling dekat dengan konsumen serta bisa jadi pengaruh dari pergaulan sekitar. Jika pengaruh internal dan eksternal kuat akan keinginan untuk mengkonsumsi buah maka kebiasaan tersebut akan lebih sering terjadi (Dian, 2006).

\section{Pengetahuan Mengenai Kandungan Buah}

Tabel 9. Pengetahuan Mengenai Kandungan Buah pada Konsumen Rumah Tangga di Kota Mataram Tahun 2021

\begin{tabular}{llrr}
\hline \multirow{2}{*}{ No } & Pengetahuan Kandungan Buah & $\begin{array}{c}\text { Jumlah } \\
\text { (Orang) }\end{array}$ & \multicolumn{2}{c}{$\begin{array}{c}\text { Persentase } \\
(\%)\end{array}$} \\
\hline 1 & Mengetahui & 58 & 82,9 \\
2 & Tidak Mengetahui & 12 & 17,1 \\
\hline & Jumlah & 70 & 100 \\
\hline
\end{tabular}

Sumber: Data Primer Diolah (2021)

Berdasarkan Tabel 9 menunjukkan bahwa sebanyak 58 orang $(82,9 \%)$ mengetahui kandungan buah yang akan dikonsumsi dan sisanya 12 orang $(17,1 \%)$ tidak mengetahui kandungan buah yang dikonsumsi. Rata-rata ketika diwawancara responden menjawab vitamin $\mathrm{C}$ dan vitamin $\mathrm{A}$ adalah kandungan terbanyak dari antara pilihan buah yang mereka pilih untuk dikonsumsi.

5. Ketersediaan Buah

Tabel 10. Faktor Ketersediaan Buah bagi Konsumen Rumah Tangga di Kota Mataram Tahun 2021

\begin{tabular}{llrrr}
\hline \multirow{2}{*}{ No } & Ketersediaan Buah & $\begin{array}{c}\text { Jumlah } \\
\text { (Orang) }\end{array}$ & \multicolumn{2}{c}{ Persentase } \\
& & & 49 & 70 \\
\hline 1 & Selalu Tersedia & 21 & 30 \\
2 & Tidak Selalu Tersedia & 70 & 100 \\
\hline
\end{tabular}

Sumber: Data Primer Diolah (2021)

Berdasarkan Tabel 10 menunjukkan bahwa faktor ketersediaan buah bagi konsumen rumah tangga di Kota Mataram Tahun 2021 sebanyak 49 orang (70\%) dari responden mengatakan bahwa buah yang akan dikonsumsi selalu tersedia di lokasi pembelian dan sisanya 21 orang (30\%) mengatakan buah tidak selalu tersedia. Konsumen rumah tangga yang mengatakan buah selalu tersedia yakni yang biasa mengkonsumsi buah apel, jeruk, pepaya, dan pisang. Sedangkan responden yang mengatakan tidak selalu tersedia biasa mengkonsumsi buah alpukat, duku, dan kelengkeng. Ketersediaan buah di pasar merupakan suatu hal yang tidak dapat dipisahkan dari konsumsi. Dimana ketersediaan buah di pasar berguna untuk memenuhi kebutuhan akan konsumsi (Wibowo, 2016). 


\section{Lokasi Pedagang}

Tabel 11. Lokasi Pedagang Buah yang Dipilih oleh Konsumen Rumah Tangga di Kota Mataram Tahun 2021

\begin{tabular}{llrr}
\hline \multirow{2}{*}{ No } & \multicolumn{1}{c}{ Lokasi Pedagang } & $\begin{array}{c}\text { Jumlah } \\
(\text { Orang) }\end{array}$ & $\begin{array}{c}\text { Persentase } \\
(\%)\end{array}$ \\
\hline 1 & Pasar Tradisional & 35 & 50,0 \\
2 & Pasar Modern & 12 & 17,2 \\
3 & Pasar Tradisional dan Pasar Modern & 8 & 11,4 \\
4 & Di Pinggir Jalan & 15 & 21,4 \\
\hline & Jumlah & 70 & 100 \\
\hline
\end{tabular}

Sumber: Data Primer diolah (2021)

Berdasarkan Tabel 11 menunjukkan bahwa lokasi pedagang buah yang paling banyak dipilih oleh konsumen adalah pasar tradisional yaitu sebanyak 35 orang (50\%). Sedangkan lokasi yang paling sedikit dipilih adalah pasar tradisional dan pasar modern yaitu sebanyak 8 orang $(11,4 \%)$. Adapun alasan yang dinyatakan oleh responden yang memilih pasar tradisional adalah banyaknya pilihan yang bisa ditemui di pasar tradisional, harga yang lebih murah dan terjangkau, dekat dengan rumah, lebih segar, lebih alami tanpa bahan pengawet dan alasan terbanyak yang dikatakan adalah karena di pasar tradisional masih ada proses tawar-menawar yang menjadi ciri khas pasar tradisional.

\section{Penerapan Pola Empat Sehat Lima Sempurna}

Tabel 12. Penerapan Pola Empat Sehat Lima Sempurna pada Konsumen Rumah Tangga di Kota Mataram Tahun 2021

\begin{tabular}{clcc}
\hline No & $\begin{array}{c}\text { Penerapan Pola Empat Sehat } \\
\text { Lima Sempurna }\end{array}$ & $\begin{array}{c}\text { Jumlah } \\
\text { (Orang) }\end{array}$ & $\begin{array}{c}\text { Persentase } \\
(\%)\end{array}$ \\
\hline 1 & Sudah Menerapkan & 32 & 45,7 \\
2 & Kadang-kadang Menerapkan & 36 & 51,4 \\
3 & Belum Menerapkan & 2 & 2,9 \\
\hline & Jumlah & 70 & 100 \\
\hline
\end{tabular}

Sumber: Data Primer diolah (2021)

Berdasarkan Tabel 12 menunjukkan bahwa sebanyak 36 orang $(51,4 \%)$ kadangkadang menerapkan pola empat sehat lima sempurna, 32 orang $(45,7 \%)$ sudah menerapkan pola empat sehat lima sempurna, dan 2 orang $(2,9 \%)$ belum menerapkan pola empat sehat lima sempurna. Dapat disimpulkan bahwa penerapan pola empat sehat lima sempurna pada konsumen skala rumah tangga di Kota Mataram masih belum terjadi secara baik dikarenakan masih ada masyarakat yang kadang-kadang menerapkan pola hidup empat sehat lima sempurna, bahkan masih ada 2 orang yang belum menerapkan. Berbagai alasan yang diberikan ketika diwawancara seperti faktor ekonomi, ada beberapa anggota keluarga yang tidak suka makan buah, dan tidak dibiasakan dalam kehidupan sehari-hari untuk mengkonsumsi buah.

\section{Intensitas Mengkonsumsi Buah}

Tabel 13. Intensitas Mengkonsumsi Buah Dalam Sehari pada Konsumen Rumah Tangga di Kota Mataram Tahun 2021

\begin{tabular}{|c|c|c|c|}
\hline No & $\begin{array}{l}\text { Intensitas Mengkonsumsi Buah } \\
\text { Dalam Sehari }\end{array}$ & $\begin{array}{l}\text { Jumlah } \\
\text { (Orang) }\end{array}$ & $\begin{array}{l}\text { Persentase } \\
(\%)\end{array}$ \\
\hline 1 & Kali Sehari & 30 & 42,9 \\
\hline
\end{tabular}




\begin{tabular}{rlrr}
2 & 2 Kali Sehari & 10 & 14,2 \\
3 & 3 Kali Sehari & 17 & 24,3 \\
4 & $>$ 3 Kali Sehari & 4 & 5,7 \\
5 & Tidak Tentu & 9 & 12,9 \\
\hline & Jumlah & 70 & 100 \\
\hline
\end{tabular}

Sumber: Data Primer Diolah (2021)

Berdasarkan data yang telah didapatkan menunjukkan bahwa intensitas mengkonsumsi buah pada konsumen rumah tangga di Kota Mataram adalah paling banyak yaitu 1 kali sehari dari jumlah keselurahan responden yang memilih yakni sebanyak 30 orang $(42,9 \%)$. Jumlah konsumsi buah 1 kali sehari tergolong sedikit jika dikaitkan dengan pola empat sehat lima sempurna. Yang mana dalam sehari jika konsumen makan sebanyak 3 kali sehari maka setidaknya konsumen makan buah minimal 3 kali dalam sehari. Masyarakat di Kota Mataram masih kurang menganggap penting buah-buahan dalam kehidupan dan pola konsumsi sehari-hari. Untuk mencukupi kebutuhan gizi, sudah dianjurkan kepada masyarakat bahwa perlu mengkonsumsi buah-buahan setiap habis makan. Sehingga sebaiknya masyarakat mengkonsumsi buah-buahan minimal 3 kali dalam sehari. Terutama untuk mencukupi anjuran kebutuhan gizi $2000 \mathrm{kkal} / \mathrm{hari}$ yang disosialisasikan oleh badan kesehatan kepada masyarakat.

Faktor-faktor yang Mempengaruhi Konsumsi Buah-buahan pada Skala Rumah Tangga di Kota Mataram

Tabel 14. Hasil Analisis Regresi Linier Berganda Faktor-faktor yang Mempengaruhi Konsumsi Buah pada Skala Rumah Tangga di Kota Mataram Tahun 2021

\begin{tabular}{lrrrr}
\hline \multicolumn{1}{c}{ Variabel } & $\begin{array}{c}\text { Koefisien } \\
\text { Regresi }\end{array}$ & $\begin{array}{c}\text { Standar } \\
\text { Error }\end{array}$ & t hitung & Signifikan \\
\hline Konstanta $(\alpha)$ & $-3,699$ & 2,393 & $-1,546$ & 0,127 \\
Jumlah Pendapatan (X1) & $3,272 \times 10^{-7}$ & 0,000 & 7,009 & 0,000 \\
Usia (X2) & 0,047 & 0,042 & 1,114 & 0,269 \\
Jumlah Anggota Keluarga & & & & \\
(X3) & 0,816 & 0,369 & 2,214 & 0,030 \\
Lama Pendidikan (X4) & 0,539 & 0,125 & 4,321 & 0,000 \\
\hline R-Square & 0,667 & & & \\
F-hitung & 32,550 & & & 0,000 \\
\hline
\end{tabular}

Sumber: Data Primer Diolah (2021)

\section{Uji Kesesuaian Model (Test of Goodness of Fit)}

\section{Koefisien Determinasi $\left(R^{2}\right)$}

Dari hasil analisis yang telah dilakukan, diperoleh nilai koefisien determinasi $\left(\mathrm{R}^{2}\right)$ sebesar 0,667 artinya 66,7\% variabel bebas (variabel jumlah pendapatan, usia, jumlah anggota keluarga dan lama pendidikan) secara simultan berpengaruh terhadap variabel terikat (jumlah konsumsi buah) dan sisanya sebesar 33,3\% dipengaruhi oleh variabel lain di luar model.

\section{Uji Serempak (Uji F - Statistik)}

Berdasarkan Tabel 14 menunjukkan bahwa hasil $\mathrm{F}$ hitung memiliki probabilitas 0,000; dimana nilai probabilitas lebih kecil dibandingkan dengan taraf nyata 0,05 (sig. F $<$ 0,05), maka Ho ditolak. Hal ini menunjukkan bahwa variabel bebas (jumlah 
pendapatan, usia, jumlah anggota keluarga, dan lama pendidikan) secara bersama-sama atau serempak berpengaruh nyata terhadap variabel terikat (jumlah konsumsi buah pada skala rumah tangga di Kota Mataram).

Berdasarkan Tabel 14 diperoleh persamaan regresi linier berganda sebagai berikut:

$$
\mathrm{Y}=-3,699+3,272 \times 10^{-7} \mathrm{X} 1+0,047 \mathrm{X} 2+0,816 \mathrm{X} 3+0,539 \mathrm{X} 4
$$

Berdasarkan persamaan di atas dapat dijelaskan bahwa:

\section{a. Konstanta}

Berdasarkan hasil analisis fungsi regresi linier berganda yang telah diperoleh menunjukkan bahwa nilai konstanta sebesar -3,699. Nilai tersebut mengandung makna jika semua variabel bebas dianggap tidak ada atau sama dengan nol, maka jumlah konsumsi buah sebesar -3,699. Nilai konstanta negatif menunjukkan penurunan jumlah konsumsi buah. Konstanta negatif dalam persamaan model regresi tidak menjadi masalah karena variabel independen dalam penelitian tidak mungkin memiliki nilai nol.

\section{b. Pengaruh Variabel Jumlah Pendapatan (X1) terhadap jumlah konsumsi buah (Y)}

Nilai koefisien regresi untuk variabel jumlah pendapatan sebesar 3,272 x $10^{-7}$. Nilai tersebut mengandung makna jika variabel lain dianggap tetap maka setiap kenaikan jumlah pendapatan konsumen sebesar Rp.1.000.000 akan menyebabkan kenaikan jumlah konsumsi buah sebesar $0,3272 \mathrm{Kg}$ atau $0,33 \mathrm{Kg} /$ bulan. Artinya apabila terjadi kenaikan jumlah pendapatan konsumen buah pada skala rumah tangga di Kota Mataram, maka jumlah konsumsi buah juga akan semakin bertambah.

Lebih lanjut dianalisis secara statistik diperoleh nilai signifikansi sebesar 0,000 yang lebih kecil dari nilai probabilitas sebesar 0,05 (sig. < 0,05), maka Ho ditolak, sehingga dapat disimpulkan bahwa variabel jumlah pendapatan konsumen berpengaruh nyata terhadap jumlah konsumsi buah atau signifikan. Konsumen rumah tangga akan membeli produk yang sesuai dengan pendapatan yang diperoleh. Bila pendapatan konsumen meningkat, maka akan meningkatkan permintaan terhadap suatu barang sehingga jumlah akan konsumsi barang tersebut akan bertambah (Setiadi, 2003). Menurut Suparyana (2017), pendapatan merupakan faktor yang penting dalam menentukan variasi permintaan terhadap berbagai jenis barang, karena besar kecilnya pendapatan dapat menggambarkan daya beli konsumen terhadap buah.

\section{c. Pengaruh Variabel usia (X2) terhadap jumlah konsumsi buah (Y)}

Berdasarkan hasil analisis fungsi regresi linier berganda yang telah diperoleh menunjukkan bahwa nilai koefisien regresi untuk variabel usia konsumen sebesar 0,047. Nilai tersebut mengandung makna jika variabel lain dianggap tetap maka setiap kenaikan usia konsumen rumah tangga sebesar 1 tahun akan menyebabkan kenaikan jumlah konsumsi buah sebesar $0,047 \mathrm{Kg} /$ bulan. Artinya apabila terjadi kenaikan jumlah usia konsumen buah pada skala rumah tangga di Kota Mataram, maka jumlah konsumsi buah juga akan semakin bertambah.

Lebih lanjut dianalisis secara statistik diperoleh nilai signifikansi sebesar 0,269 yang lebih besar dari nilai probabilitas sebesar 0,05 (sig. > 0,05), maka Ho diterima, sehingga dapat disimpulkan bahwa variabel usia konsumen rumah tangga tidak berpengaruh nyata terhadap jumlah konsumsi buah atau tidak signifikan. Semakin bertambah usia seseorang semakin sadar akan pentingnya kesehatan dengan cara mengubah gaya hidup yang lebih baik seperti mengkonsumsi buah setiap hari (Setyani, 2006).

\section{d. Pengaruh variabel jumlah anggota keluarga (X3) terhadap jumlah konsumsi buah} (Y)

Berdasarkan hasil analisis fungsi regresi linier berganda yang telah diperoleh menunjukkan bahwa nilai koefisien regresi untuk jumlah anggota keluarga sebesar 
0,816 . Nilai tersebut mengandung makna jika variabel lain dianggap tetap maka setiap penambahan anggota keluarga sebesar 1 orang akan menyebabkan kenaikan jumlah konsumsi buah sebesar $0,816 \mathrm{Kg} /$ bulan. Artinya apabila semakin banyak jumlah anggota keluarga konsumen buah pada skala rumah tangga di Kota Mataram, maka jumlah konsumsi buah juga akan semakin bertambah.

Lebih lanjut dianalisis secara statistik diperoleh nilai signifikansi sebesar 0,030 yang lebih kecil dari nilai probabilitas sebesar 0,05 (sig. < 0,05), maka Ho ditolak, sehingga dapat disimpulkan bahwa variabel jumlah anggota keluarga berpengaruh nyata terhadap jumlah konsumsi buah atau signifikan. Jumlah anggota keluarga merupakan salah satu faktor yang mempengaruhi pola konsumsi rumah tangga. Banyaknya anggota keluarga, maka pola konsumsinya semakin bervariasi karena masing-masing anggota rumah tangga belum tentu mempunyai selera yang sama. Semakin banyak anggota keluarga semakin bertambah pula jumlah konsumsi buah pada rumah tangga tersebut. Jumlah anggota keluarga berkaitan dengan pendapatan rumah tangga yang akhirnya akan mempengaruhi jumlah konsumsi buah. Jumlah anggota keluarga sangat menentukan jumlah kebutuhan keluarga. Semakin banyak anggota keluarga berarti semakin banyak pula jumlah kebutuhan keluarga yang harus dipenuhi. Begitu pula sebaliknya, semakin sedikit anggota keluarga berarti semakin sedikit pula kebutuhan yang harus dipenuhi keluarga. Sehingga dalam keluarga yang jumlah anggotanya banyak, akan diikuti oleh banyaknya kebutuhan yang harus dipenuhi (Erwin, 2012).

\section{e. Pengaruh variabel lama pendidikan (X4) terhadap jumlah konsumsi buah (Y)}

Berdasarkan hasil analisis fungsi regresi linier berganda yang telah diperoleh menunjukkan bahwa nilai koefisien regresi untuk variabel lama pendidikan sebesar 0,539 . Nilai tersebut mengandung makna jika variabel lain dianggap tetap maka setiap kenaikan lama pendidikan konsumen rumah tangga sebesar 1 tahun akan menyebabkan kenaikan jumlah konsumsi buah sebesar $0,539 \mathrm{Kg} /$ bulan. Artinya apabila semakin tinggi tingkat pendidikan konsumen buah pada skala rumah tangga di Kota Mataram, maka jumlah konsumsi buah juga akan semakin bertambah.

Lebih lanjut dianalisis secara statistik diperoleh nilai signifikansi sebesar 0,000 yang lebih kecil dari nilai probabilitas sebesar 0,05 (sig. < 0,05), maka Ho ditolak, sehingga dapat disimpulkan bahwa variabel tingkat pendidikan berpengaruh nyata terhadap jumlah konsumsi buah atau signifikan. Artinya tingkat pendidikan konsumen buah pada skala rumah tangga di Kota Mataram berpengaruh nyata pada jumlah konsumsi buah atau signifikan. Tingkat pendidikan yang lebih tinggi diharapkan memudahkan seseorang atau masyarakat untuk menyerap informasi dan mengimplementasikannya dalam perilaku dan gaya hidup sehari-hari. Perilaku konsumsi makan seperti halnya perilaku lainnya pada diri seseorang, satu keluarga atau masyarakat dipengaruhi oleh wawasan dan cara pandang serta faktor lain yang berhubungan dengan tindakan yang tepat berkaitan dengan informasi tentang makanan dan gizi yang diterimanya dari berbagai sumber (Notoatmodjo, 2007).

\section{Uji Asumsi Klasik}

a. Uji Normalitas

Dalam penelitian ini, uji normalitas dilakukan dengan uji Kolmogorov-Smirnov. Jika Sig.KS $>0,05$ artinya data berdistribusi normal. 
Tabel 15. Hasil Analisis SPSS untuk Uji Normalitas

\begin{tabular}{llr}
\hline \multicolumn{2}{c}{ One-Sample Kolmogorov-Smirnov Test } \\
\hline $\mathrm{N}$ & & Unstandardized Residual \\
Normal Parameters ${ }^{\mathrm{a}}$ & Mean & 70 \\
& Std. Deviation & .0000000 \\
Most Extreme Differences & Absolute & 3.26278855 \\
& Positive & .091 \\
& Negative & .091 \\
Kolmogorov-Smirnov Z & & -.074 \\
Asymp. Sig. (2-tailed) & & .764 \\
a. Test distribution is Normal. & .603 \\
\hline
\end{tabular}

Sumber: Data Primer diolah (2021)

Tabel 15 menunjukkan bahwa setelah melakukan uji Kolmogorov-Smirnov, diperoleh signifikansi sebesar 0,603 > 0,05 yang artinya data terdistribusi normal.

b. Uji Heteroskedastisitas

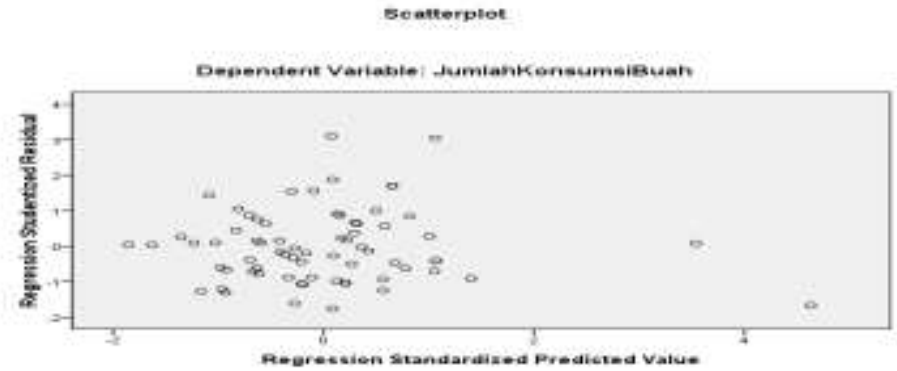

Gambar 1. Grafik Scatterplot

Berdasarkan Gambar 1 menunjukkan bahwa tidak ada pola yang jelas serta titik-titik tersebut menyebar di atas dan di bawah angka 0 pada sumbu Y. Hal ini menunjukkan bahwa data dalam penelitian ini tidak terjadi heteroskedastisitas.

c. Uji Multikolinieritas

Jika nilai tolerance $\geq 0,10$ dan nilai $\mathrm{VIF} \leq 10$, maka model regresi tidak mengalami gejala multikolinieritas.

Tabel 16. Hasil Analisis SPSS untuk Uji Multikolinieritas

Coefficients $^{\mathrm{a}}$

\begin{tabular}{|c|c|c|c|c|c|c|c|c|}
\hline \multirow{2}{*}{\multicolumn{2}{|c|}{ Model }} & \multicolumn{2}{|c|}{$\begin{array}{l}\text { Unstandardized } \\
\text { Coefficients }\end{array}$} & $\begin{array}{c}\text { Standardized } \\
\text { Coefficients } \\
\end{array}$ & \multirow[b]{2}{*}{$\mathrm{t}$} & \multirow[b]{2}{*}{ Sig. } & \multicolumn{2}{|c|}{ Collinearity Statistics } \\
\hline & & B & $\begin{array}{l}\text { Std. } \\
\text { Error }\end{array}$ & Beta & & & Tolerance & VIF \\
\hline 1 & (Constant) & -3.699 & 2.393 & & -1.546 & .127 & & \\
\hline & $\begin{array}{l}\text { Jumlah } \\
\text { Pendapatan }\end{array}$ & $\begin{array}{r}3.272 \mathrm{E} \\
-7\end{array}$ & .000 & .578 & 7.009 & .000 & .754 & 1.327 \\
\hline & Usia & .047 & .042 & .085 & 1.114 & .269 & .887 & 1.127 \\
\hline
\end{tabular}


Jumlah

Anggota

.816

.369

$.170 \quad 2.214$

.030

.873

1.145

Keluarga

Lama

Pendidikan

.125

$.357 \quad 4.321$

.000

.751

1.331

a. Dependent Variable: Jumlah Konsumsi Buah

Sumber: Data Primer Diolah (2021)

Melihat hasil perhitungan nilai tolerance dan VIF dapat disimpulkan bahwa tidak ada gejala multikolinieritas antar variabel independen dalam model regresi.

\section{KESIMPULAN DAN SARAN}

\section{Kesimpulan}

Berdasarkan hasil penelitian yang telah dilakukan, maka dapat ditarik kesimpulan sebagai berikut:

1. Gambaran umum pola konsumsi buah-buahan pada konsumen rumah tangga di Kota Mataram yaitu buah yang paling banyak diminati oleh konsumen adalah buah lokal. Jenis buah yang dipilih untuk dikonsumsi oleh konsumen rumah tangga sangat bervariasi. Jumlah buah yang paling banyak diminati yaitu buah Jeruk Lokal, sedangkan yang paling sedikit diminati yaitu buah Alpukat Lokal dan Duku Lokal. Kebiasaan mengkonsumsi buah pada konsumen rumah tangga di Kota Mataram rata-rata adalah suka dan sering mengkonsumsi buah. Rata-rata konsumen mengetahui kandungan buah yang akan mereka konsumsi dan buah selalu tersedia. Lokasi pembelian buah yang paling banyak adalah pasar tradisional. Konsumen rumah tangga sebagian besar kadang-kadang menerapkan pola empat sehat lima sempurna dengan mengkonsumsi buah minimal 1 kali sehari.

2. Faktor-faktor yang mempengaruhi konsumsi buah-buahan pada konsumen rumah tangga di Kota Mataram yaitu jumlah pendapatan, usia, jumlah anggota keluarga dan lama pendidikan berpengaruh nyata secara serempak terhadap jumlah konsumsi buah. Jumlah pendapatan, jumlah anggota keluarga, dan lama pendidikan berpengaruh nyata secara parsial terhadap jumlah konsumsi buah, sedangkan usia tidak berpengaruh nyata secara parsial terhadap jumlah konsumsi buah.

\section{Saran}

Berdasarkan uraian dan kesimpulan yang telah didapat, maka dikemukakan saran sebagai berikut:

1. Kepada masyarakat agar selalu membiasakan diri dalam mengkonsumsi buah di kehidupan sehari-hari guna menerapkan pola empat sehat lima sempurna.

2. Kepada badan-badan kesehatan disarankan untuk mensosialisasikan gaya hidup sehat dengan wajib mengkonsumsi buah-buahan setiap hari dan mengajarkan makan buah setiap kali selesai makan kepada masyarakat.

3. Kepada peneliti lain diharapkan untuk melanjutkan dan mengkaji lebih dalam tentang penelitian ini dan mengetahui faktor lain yang mempengaruhi konsumsi buah-buahan pada masyarakat. 


\section{DAFTAR PUSTAKA}

Dalimartha, S dan Adrian, F. (2011). Khasiat Buah dan Sayur. Jakarta: Penebar Swadaya.

Desfaryani, R., Hartoyo, S., \& Anggraeni, L. (2016). Permintaan Buah-buahan Rumahtangga di Propinsi Lampung. Jurnal Agribisnis Indonesia (Journal of Indonesian Agribusiness), 4(2), 137-148.

Gujarati, D.N. (2006). Ekonometrika Dasar. Jakarta: Penerbit Erlangga.

Hendriadi, A. (2013). Optimalisasi Kegiatan Litkajibangdiklatluh dan Corporate Management Untuk Peningkatan Kinerja LitbangHortikultura. Rapat Kerja Pusat Penelitian Pengembangan Hortikultura Badan Penelitian dan Pengembangan Pertanian 26-29 Maret 2013.

Septiadi, D., \& Nursan, M. (2021). Optimasi Produksi Usaha Tani Sebagai Upaya Peningkatan Pendapatan Petani Sayuran Di Kota Mataram. Agrifo, Jurnal Agribisnis Universitas Malikussaleh, 5(2), 87-96.

Septiadi, D., \& Mundiyah, A. I. (2020). Strategi Pengembangan Usaha Tani Sayuran Berbasis Pertanian Organik. Agrifo: Jurnal Agribisnis Universitas Malikussaleh, $5(1), 35-43$.

Setiadi, N.J. (2003). Perilaku Konsumen : Konsep dan Implikasi Untuk Strategi dan Penelitian Pemasaran. Jakarta: Kencana.

Simamora, B. (2004). Panduan Riset Perilaku Konsumen. Jakarta: Gramedia.

Sriwijayanti, E., Sinaga, B. M., \& Kuntjoro, S. U. (2004). Analisis pola permintaan dan pengeluaran konsumsi buah-buahan di DKI Jakarta (analysis of demand and expenditure of fruits consumption in Jakarta). [Tesis]. Bogor: Institut Pertanian Bogor.

Sumarwan, U. (2015). Pemasaran Strategik: Prespektif Perilaku Konsumen, dan Marketing Plan. Jakarta: PT.Ghalia Indonesia.

Suparyana, P. K., Ramantha, W., \& Budiasa, W. (2017). Analisis Permintaan Buah Pisang Di Kota Denpasar, Bali. Jurnal Manajemen Agribisnis, 5(1).

Tanaya, I. G. L. P., Rosmilawati, R., Hidayati, A., \& Septiadi, D. (2021). Analisis Risiko Produksi Spesialisasi Tanaman Hortikultura di Kabupaten Lombok Utara (Analysis of the Risk of Production for Horticultural Specialties in North Lombok Regency). Prosiding SAINTEK, 3, 315-327.

Wardani, T. P. K. (2007). Analisis pola konsumsi dan permintaan buah pada tingkat rumah tangga di Pulau Jawa penerapan model Almost Ideal Demand System (AIDS). [Tesis]. Bogor: Institut Pertanian Bogor.

Wibowo, (2016). Manajemen Kinerja Edisi Kelima. Jakarta: PT Rajagrafindo Persada Jakarta-14240.

Wirawan, I. G. Y., \& Antara, M. (2013). Permintaan Buah Pisang Ambon Oleh Rumah Tangga di Kecamatan Denpasar Barat, Kota Denpasar, Provinsi Bali. Jurnal Ekonomi Kuantitatif Terapan, 6(1), 44298.

Yuliastuti, E. R., Dwiastuti, R., \& Hanani, N. (2014). Analisis Dinamis Permintaan Buah-Buahan Di Indonesia: Pendekatan Model Error Correction-Linear Approximation Almost Ideal Demand System. Agricultural Socio-Economics Journal, 14(3), 238. 